\title{
Germination of Archontophoenix cunninghamiana (Australian king palm) seeds based on different temperatures and substrates ${ }^{(1)}$
}

\author{
PETTERSON BAPTISTA DA LUZ ${ }^{(2)}$, ARMANDO REIS TAVARES ${ }^{(3)}$, \\ KATHIA FERNANDES LOPES PIVETTA ${ }^{(4)}$
}

\begin{abstract}
Archontophoenix cunninghamiana or Australian King Palm, is a very popular ornamental palm in Brazil. Although A. cunninghamiana is propagated by seeds, few studies have reported on seed germination of this species. Therefore, this study aimed to evaluate the effect of different temperatures and substrates on the germination of $A$. cunninghamiana seeds. To carry out the temperature experiment, constant temperatures of $20,25,30$ or $35{ }^{\circ} \mathrm{C}$ and alternating temperatures of $20 / 30{ }^{\circ} \mathrm{C}$ or $25 / 35{ }^{\circ} \mathrm{C}$ were used with four replications of 25 seeds each. For the substrate experiment, sand, vermiculite, and sphagnum moss were used with 7 replicates of 25 seeds per treatment in a completely randomized design. All temperatures, except $35^{\circ} \mathrm{C}$, favored the germination of $A$. cunninghamiana seeds $(60 \%)$. Vermiculite was determined to be best suited for the germination of $A$. cunninghamiana seeds. Overall, the germination of $A$. cunninghamiana seeds is slow and uneven, in turn allowing for a longer period of germination.
\end{abstract}

Keywords: Archontophoenix cunninghamiana, diaspore, germination index, Palmae.

\section{RESUMO}

Germinação de sementes de Archontophoenix cunninghamiana (Palmeira real australiana) em diferentes temperaturas e substratos

Archontophoenix cunninghamiana ou palmeira real australiana, é uma palmeira ornamental muito popular no Brasil. Embora $A$. cunninghamiana seja propagada por sementes, poucos estudos têm relatado a germinação de sementes da espécie. Portanto, este estudo teve como objetivo avaliar o efeito de diferentes temperaturas e substratos na germinação de sementes de $A$. cunninghamiana. Para o experimento de temperatura foram utilizadas as temperaturas constantes de $20,25,30$ ou $35^{\circ} \mathrm{C}$ e temperaturas alternadas de $20 / 30{ }^{\circ} \mathrm{C}$ ou $25 / 35{ }^{\circ} \mathrm{C}$ com quatro repetições de 25 sementes cada. Para a experiência do substrato, foram utilizados areia, vermiculita e musgo esfagno com 7 repetições de 25 sementes por tratamento, em delineamento inteiramente casualizado. Todas as temperaturas, exceto $35^{\circ} \mathrm{C}$, favoreceram a germinação de sementes de $A$. cunninghamiana $(60 \%)$. A vermiculita foi o substrato mais adequado para a germinação de sementes de $A$. cunninghamiana. Em geral, a germinação de sementes de $A$. cunninghamiana foi lenta e desigual, por sua vez, permitindo um período mais longo de germinação.

Palavras-chave: Archontophoenix cunninghamiana, diasporo, índice de germinação, Palmae.

\section{INTRODUCTION}

Archontophoenix cunninghamiana is popularly known as Australian King Palm for its native region of Queensland in eastern Australia (LUZ and PIVETTA, 2010). This species has a simple trunk 8 to $10 \mathrm{~m}$ high and $18 \mathrm{~cm}$ in diameter, cylindrical stipe, 2-3 m long pinnate leaves, white-colored, branched inflorescences when young and reddish spherical fruits (LORENZI, 2004). A. cunninghamiana became an option for heart of palm production as a replacement for the predatory exploitation of native species, especially Euterpe edulis (MARTINS et al., 2003). However, the introduction of the King Palm has led to its invasion of remaining Atlantic Forest fragments. The interaction between plants of the genus Archontophoenix and local avifauna is evident, indicating the consumption of fruits and dispersal of seeds by frugivorous birds (MENGARDO, 2014).

Palm trees are mainly propagated by seeds. Several factors affect uniformity and percentage of seed germination. Palm seed germination is usually slow, uneven and low (BROSCHAT, 1994). Temperatures between 20 and $40{ }^{\circ} \mathrm{C}$ are acceptable for palm seed germination, with best results for most palm species at 30 and $35{ }^{\circ} \mathrm{C}$ (MEEROW, 1991, BROSCHAT, 1994). However, studies have shown that different species of palms require different ranges of temperatures for germination, such as $35^{\circ} \mathrm{C}$ for Thrinax parviflora (PIVETTA et al., 2005a), 25 to $30^{\circ} \mathrm{C}$ for Phoenix roebelenii (IOSSI et al., 2003) and Rhapis excelsa (LUZ et al., 2008a), and 30 to $35{ }^{\circ} \mathrm{C}$ for Syagrus romanzoffiana (PIVETTA et al., 2005b). 20 to $30{ }^{\circ} \mathrm{C}$ for

\footnotetext{
DOI: http://dx.doi.org/10.14295/oh.v23i2.889

(1) Received in 05/04/2016 and accepted in 06/06/2017

(2) Universidade do Estado de Mato Grosso (UNEMAT), Cáceres-MT, Brazil. *Corresponding author: petterbaptista@yahoo.com.br

(3) Instituto de Botânica (IBt), São Paulo-SP, Brazil.

(4) Universidade Estadual Paulista (UNESP), Jaboticabal-SP, Brazil.

Licensed by CC BY 4.0
} 
Phoenix canariensis (PIMENTA et al., 2010), alternate 20$30{ }^{\circ} \mathrm{C}$ for $A$. alexandrae (MARTINS et al., 2011), 25 to 35 ${ }^{\circ} \mathrm{C}$ for Livistona chinensis (KOBORI et al., 2009), and 24 to $29{ }^{\circ} \mathrm{C}$ for Dypsis decaryi (LUZ et al., 2008b).

Substrate characteristics, such as structure, aeration, water retention capacity and degree of pathogen infestation, may vary according to the type of material used and have a major influence on germination rates (POPINIGIS, 1977). Vermiculite has been recommended as an excellent substrate for seed germination (PIVETTA et al., 2008), although it is not prescribed in the Rules for Seed Analysis (BRASIL, 2009). Vermiculite is free of pests and diseases, has good drainage and water retention capacity, and has been recommended as a substrate for palm seed germination (NAZARIO and FERREIRA, 2010).

This study aimed to evaluate the germination of $A$. cunninghamiana seeds under different temperatures and substrates, due to the specie importance for landscape and floriculture and, nowadays as an important invasive species in tropical areas.

\section{MATERIAL AND METHODS}

A. cunninghamiana seeds were harvested from 10 plants on period of may/june at Jaboticabal, São Paulo State, Brazil. Readily after the harvest mature fruits (red color) were selected and depulped with exocarp and mesocarp removed by friction against a steel mesh screen under running water. After processing, seed moisture content was determined on 5 samples with 20 seeds each by oven drying at $105{ }^{\circ} \mathrm{C}$ for 24 hours (BRASIL, 2009). The seed moisture content of the seeds was $36.23 \%$.

The study comprised of two experiments: 1 . The substrate experiment was carried out in sand, vermiculite or sphagnum in alternating temperatures of $25 / 35^{\circ} \mathrm{C}$, with seven repetitions of 25 seeds each. 2. The temperature experiment was carried out under constant temperatures of $20,25,30$ or 35 ${ }^{\circ} \mathrm{C}$ and alternating temperatures of $20 / 30{ }^{\circ} \mathrm{C}$ or $25 / 35^{\circ} \mathrm{C}$ on vermiculite, with four repetitions of 25 seeds each.

The trays were kept in a BOD (Biochemical Oxygen Demand)-type germination chamber with photoperiod of 8 hours of light and 16 hours of darkness in transparent plastic boxes (Gerbox). Irrigation was performed as necessary using distilled water with $0.2 \%$ nystatin for fungal control. The germination test was conducted over a period of 45 days or when seed germination was no longer observed.

The germination percentage, calculated in accordance with the Rules for Seed Analysis (BRASIL, 2009), and the germination speed index (GSI), calculated according to Maguire formula (1962), were determined. The germination criterion used to calculate in vitro germination (IVG) and germination percentage (GP) was the primary root protrusion $(0.1 \mathrm{~cm})$.

Data were analyzed for variance and means compared using the Scott-Knott test at $5 \%$ probability. The GP data were transformed to $\arcsin (\mathrm{x} / 100)^{1 / 2}$. The statistical analyses were performed by using the statistical program SISVAR.

\section{RESULTS AND DISCUSSION}

Seed moisture content of $A$. cunninghamiana at harvest was $36.23 \%$. Water contents lower than $31.5 \%$ significantly reduced the germination rate in $A$. alexandrae seeds and the total loss of germination capacity was verified in seeds with $15.1 \%$ of humidity (MARTINS et al., 2003). Seed germination under different temperatures began on the sixth day at temperatures of $25^{\circ} \mathrm{C}, 30{ }^{\circ} \mathrm{C}, 35^{\circ} \mathrm{C}, 20 / 30$, and $25 / 35{ }^{\circ} \mathrm{C}$, and on the ninth day at $20^{\circ} \mathrm{C}$. The highest GP occurred between the $6^{\text {th }}$ and $9^{\text {th }}$ days, except for the constant temperature of $20^{\circ} \mathrm{C}$, which started later, between the $14^{\text {th }}$ and $16^{\text {th }}$ days (Table 1 ).

Table 1. Germination percentage (GS) and germination speed (IVG) of A. cunninghamiana seeds under different temperatures.

\begin{tabular}{|c|c|c|}
\hline Temperature $\left({ }^{\circ} \mathbf{C}\right)$ & Germination $(\mathbf{\%})$ & IVG \\
\hline 20 & $92^{\mathrm{A}}$ & $1.24^{\mathrm{B}}$ \\
\hline 25 & $94^{\mathrm{A}}$ & $2.86^{\mathrm{A}}$ \\
\hline 30 & $93^{\mathrm{A}}$ & $2.65^{\mathrm{A}}$ \\
\hline 35 & $63^{\mathrm{B}}$ & $2.14^{\mathrm{A}}$ \\
\hline $20-30$ & $91^{\mathrm{A}}$ & $2.59^{\mathrm{A}}$ \\
\hline $25-35$ & $94^{\mathrm{A}}$ & $3.05^{\mathrm{A}}$ \\
\hline $\mathrm{CV}(\%)$ & 13.84 & 17.81 \\
\hline
\end{tabular}

Means followed by the same letter do not differ by Scott-Knott test at 5\% of probability. CV - coefficient of variance.

Seed germination of $A$. cunninghamiana occurred with the opening of a circular operculum on the dorsal face of the seed through which emitted the cotyledonary petiole that grew up to $3 \mathrm{~cm}$ when the edge expanded and began to grow the primary root between the $6^{\text {th }}$ and $45^{\text {th }}$ days (LUZ et al., 2012). Most palms are of tropical origin, and their seeds germinate naturally at temperatures higher than 20 ${ }^{\circ} \mathrm{C}$, such as $25^{\circ} \mathrm{C}$ for $A$. alexandrae (TEIXEIRA et al., 2011), 25 or $30^{\circ} \mathrm{C}$ for $A$. cunninghamii (PIVETTA et al., 2008) and $25^{\circ} \mathrm{C}$ for Rhapis excelsa (AGUIAR et al., 2005). 
Temperatures below 5 to $10^{\circ} \mathrm{C}$ and above $35^{\circ} \mathrm{C}$ delay and reduce palm seed germination, which then becomes erratic and lacks uniformity (CARPENTER, 1988). Matthes and Castro (1987) obtained different results on the number of days required for germination of $A$. cunninghamiana seeds; the germination period was 52 to 63 days after sowing; however, the authors did not describe the temperature range or how the seeds were sowed during the germination period.

A temperature of $35{ }^{\circ} \mathrm{C}$ decreased GP by $20 \%$ and should therefore not be used for germination of $A$. cunninghamiana (Table 1). Teixeira et al. (2011) also observed that GP was lower at $35^{\circ} \mathrm{C}$, when compared to alternating temperatures on $A$. alexandrae seed germination. Alternating temperatures of 20/30 and 25/35 ${ }^{\circ} \mathrm{C}$ and constant temperatures of 25,30 or $35^{\circ} \mathrm{C}$ showed the highest IVG for A. cunninghamiana seeds (3.05) in our study. Rhapis excelsa palms had the highest IVG at $25^{\circ} \mathrm{C}$ (AGUIAR et al., 2005), and seeds of Oenocarpus minor had the highest IVG at $30{ }^{\circ} \mathrm{C}$ (SILVA et al., 2006).

The substrate vermiculite had a significant effect on seed germination of $A$. cunninghamiana, affording a GP of $93.14 \%$. Sphagnum and sand had a lower percentage of seed germination with 62 and 68\%, respectively (Table 2).

Table 2. Germination percentage and germination speed (IVG) of A. cunninghamiana seeds in different substrates.

\begin{tabular}{|c|c|c|}
\hline Substrate & Germination (\%) & IVG \\
\hline Sand & $86.28^{\mathrm{B}}$ & $1.56^{\mathrm{A}}$ \\
\hline Vermiculite & $93.14^{\mathrm{A}}$ & $1.93^{\mathrm{A}}$ \\
\hline Sphagnum Moss & $78.85^{\mathrm{B}}$ & $1.51^{\mathrm{A}}$ \\
\hline CV(\%) & 9.40 & 22.20 \\
\hline
\end{tabular}

Means followed by the same letter do not differ by Scott-Knott test at $5 \%$ of probability. CV - coefficient of variance.

Micron vermiculite moistened with 1.0 times its weight with water was had the best performance as substrate for A. alexandrae seeds germination, inducing maximum seed germination and germination rate (MARTINS et al., 2011). Charlo et al. (2006) observed the highest seed germination rates for $A$. alexandrae on the commercial substrate Plantmax with $86.3 \%$ germination, even higher than sand. According to the authors, the high drainage of the sandy substrate reduced the availability of water, while in soil and TAE (mixture of soil, sand and manure), even the most superficial compression represents a mechanical barrier to seedlings emerge.

No difference was observed for IVG among the substrates tested. Seed germination of $A$. cunninghamiana was irregular (Figure 1), thus reinforcing the study of Broschat (1994) who reported that palm seed germination tends to be slow and uneven. 

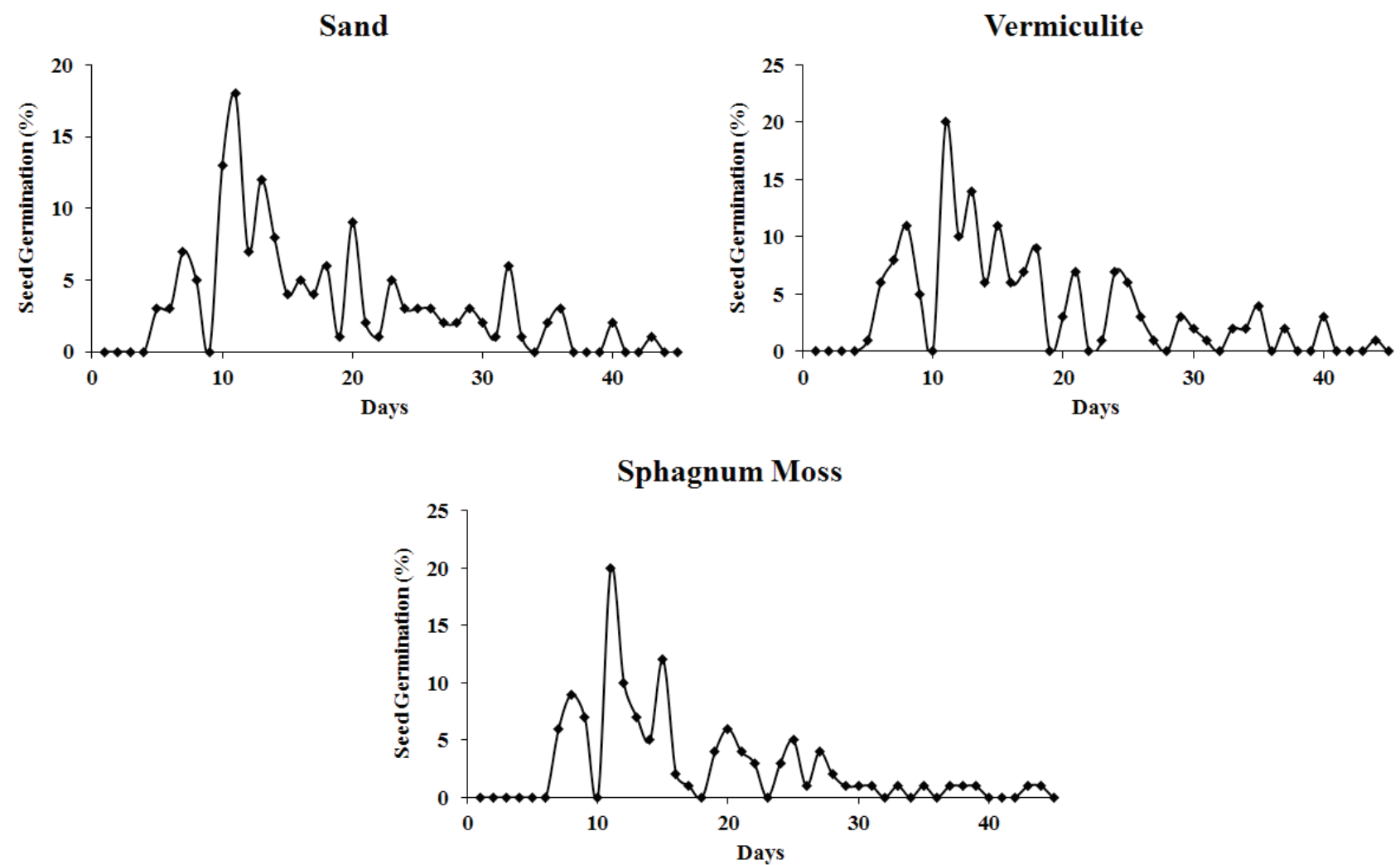

Figure 1. Seed germination (\%) of $A$. cunninghamiana in different substrates.

This characteristic may explain successful invasion and adaptation in Brazilian forests in that slow and uneven germination ensures that sprouting will occur when conditions become more suitable. Based on such evidence, studies on the germination of plant species can help gain insight into the mechanisms that operate in the invasion process, leading to appropriate methods of species control (CHRISTIANINI, 2006).

\section{CONCLUSIONS}

Alternated temperatures of $25 / 35{ }^{\circ} \mathrm{C}$ and constant temperature of $25{ }^{\circ} \mathrm{C}$ resulted in the highest GP and GRI for A. cunninghamiana. Although no substrate increased GR and the best substrate for $A$. cunninghamiana seed germination was vermiculite.

\section{AUTHORS CONTRIBUTIONS}

P.B.L.: Conception or design of the work, data collection, data analysis and interpretation, drafting the article. A.R.T.: Data analysis and interpretation, drafting and critical revision of the article. K.F.L.P.: Conception of the work, data analysis and interpretation, drafting and critical revision of the article, final approval of the version to be published.

\section{REFERENCES}

AGUIAR, F.F.A.; BILIA, D.A.C.; KANASHIRO, S.; TAVARES, A.R.; BARBEDO, C.J. Germinação de sementes de Rhapis excelsa (Thunb.) Henry ex Rehder: efeitos da temperatura, luz e substrato. Hoehnea, v.32, p.119-126, 2005. DOI: <http://www.ambiente.sp.gov.br/ hoehnea/files/2015/07/321_T09_24_07_2015.pdf>

BRASIL. MINISTERIO DA AGRICULTURA, PECUARIA E ABASTECIMENTO. Regras para análise de sementes. Brasília: Mapa/ACS, 2009. 399p.

BROSCHAT, T.K. Palm seed propagation. Acta Horticulturae, v.360, p.141-147, 1994.

BROSCHAT, T.K.; DONSELMAN, H. Factors affecting storage and germination of Chrysalidocarpus lutescens seeds. Journal American Society for Horticultural Science, v.111, p.872-877, 1986.

CARPENTER, W.J. Temperature affects seed germination of four Florida palms species. HortScience, v.23, p.336337, 1988. 
CHARLO, H.C.O.; MÔRO, F.V.; SILVA, V.L.; SILVA, B.M.; MÔRO, J.R. Aspectos morfológicos, germinação e desenvolvimento inicial de plântulas de Archontophoenix alexandrae (F. Mueller) H. Wendl. e Drude (Arecaceae) em diferentes substratos. Revista Árvore, v.3, p.933-940, 2006. DOI: <http://www.scielo.br/scielo.php?script=sci_ar ttext\&pid=S0100-67622006000600008>

CHRISTIANINI, A.V. Fecundidade, dispersão e predação de sementes de Archontophoenix cunninghamiana $\mathrm{H}$. Wendl. \& Drude, uma palmeira invasora da Mata Atlântica. Revista Brasileira de Botânica, v.29, p.587-594, 2006. DOI: $<$ http://www.scielo.br/scielo.php?script=sci arttext \&pid $=$ S0100-84042006000400008>

IOSSI, E.; SADER, R.; PIVETTA, K.F.L.; BARBOSA, J.C. Efeitos de substratos e temperaturas na germinação de sementes de tamareira-anã (Phoenix roebelenii O'Brien). Revista Brasileira de Sementes, v.25, p.63-69, 2003. DOI: $<$ http://www.scielo.br/scielo.php?script=sci arttext \&pid $=$ S0101-31222003000400009>

KOBORI, N.N.; PIVETTA, K.F.L.; DEMATTÊ, M.E.S.P.; SILVA, B.M.S.; LUZ, P.B.; PIMENTA, R.S. Efeito da temperatura e do regime de luz na germinação de sementes de palmeira-leque-da-China (Livistona chinensis (Jack.) R.Br. ex Mart.). Revista Brasileira de Horticultura Ornamental, v.15, p.29-35, 2009. DOI: <http:// ornamentalhorticulture.emnuvens.com.br/rbho/article/ viewFile/432/331>

LORENZI, H. Palmeiras brasileiras exóticas e cultivadas. Nova Odessa: Instituto Plantarum, 2004. 416p.

LUZ, P.B.; PIMENTA, R.S.; PIZETTA, P.U.C.; CASTRO, A.; PIVETTA, K.F.L. Germinação de sementes de Dypsis decaryi (Jum.) Beentje \& J. Dransf. (Arecaceae). Ciência e Agrotecnologia, v.32, p.1461-1466, 2008b. DOI: $<$ http://www.scielo.br/scielo.php?script=sci_arttext\&pid $=$ S1413-70542008000500016>

LUZ, P.B.; PIVETTA, K.F.L. Armazenamento de sementes de Archontophoenix cunninghamii H. Wendl. \& Drude (Palmeira real australiana). Scientia Agraria, v.11, p.349354, 2010. DOI: <http://ojs.c3sl.ufpr.br/ojs/index.php/ agraria/article/view/18271/11959>

LUZ, P.B.; PIVETTA, K.F.L.; NEVES, L.G.; SOBRINHO, S.P.; BARELLI, M.A.A. Caracterização morfológica da semente e da plântula de Archontophoenix cunninghamii (Arecaceae). Comunicata Scientiae, v.3, p.244-248, 2012.

LUZ, P.B.; TAVARES, A.R.; PAIVA, P.O.D.; AGUIAR, F.F.A.; KANASHIRO, S. Germinação de sementes de palmeira-ráfia: efeito de tratamentos pré-germinativos. Revista Árvore, v.32, p.793-798, 2008a. DOI: <http:// www.scielo.br/scielo.php?script $=$ sci_arttext\&pid $=$ S0100-67622008000500002>
MAGUIRE, J.D. Speed of germination aid in selection and evaluation of seedling emergence and vigor. Crop Science, v.2, p.176-177, 1962.

MARTINS, C.C.; BOVI, M.L.; NAKAGAWA, J. Desiccation effects on germination and vigor of King palm seeds. Horticultura Brasileira, v.21, p.88-92, 2003. DOI: $<$ http://www.scielo.br/scielo.php?script=sci_arttext\&pid $=$ S0102-05362003000100019>

MARTINS, C.C.; CALDAS, I.G.R.; MACHADO, C.G.; Dourado, W.S. Tipos de substratos para germinação de sementes de palmeira-real-australiana (Archontophoenix alexandrae H. Wendl. \& Drude). Revista Árvore, v.35, n.6, p.1189-1196, 2011. DOI: <http://dx.doi.org/10.1590/ S0100-67622011000700005>

MATTHES, L.A.F.; CASTRO, C.E.F. Germinação de sementes de palmeiras. O Agronômico, v.39, p.267-277, 1987.

MEEROW, A.W. Palm Seed Germination. Fort Lauderdale: Cooperative Extension Service, 1991. 10p.

MENGARDO, A.L.T.; PIVELLO, V.R. The effects of an exotic palm on a native palm during the first demographic stages: contributions to ecological management. Acta Botanica Brasilica, v.28, n.4, 2014. DOI: <http://www. scielo.br/scielo.php?script $=$ sci_arttext\&pid=S010233062014000400009\&lng=en\&nrm $=$ iso $>$

NAZARIO, P.; FERREIRA, S.A.N. Emergência de plântulas de Astrocaryum aculeatum G. May. em função da temperatura e do período de embebição das sementes. Acta Amazonica, v.40, p.165-170, 2010. DOI: <http:// www.scielo.br/scielo.php?script $=$ sci_arttext\&pid $=$ S0044-59672010000100021>

PIMENTA, R.S.; LUZ, P.B.; PIVETTA, K.F.L.; CASTRO, A.; PIZETTA, P.U.C. Efeito da maturação e temperatura na germinação de sementes de Phoenix canariensis hort. ex Chabaud - Arecaceae. Revista Árvore, v.34, p.31-38, 2010. DOI: <http://www.scielo.br/scielo.php?script=sci_ar ttext\&pid=S0100-67622010000100004>

PIVETTA, K.F.L.; CASALI, L.P.; CINTRA, G.S.; PEDRINHO, D.R.; PIZETTA, P.U.C.; PIMENTA, R.S.; FABRINO, C.; MATTIUZ, M. Efeito da temperatura e do armazenamento na germinação de sementes de Thrinax parviflora Swartz. (Arecaceae). Científica, v.33, p.178184, 2005a. DOI: <http://cientifica.org.br/index.php/ cientifica/article/view/51/32>

PIVETTA, K.F.L.; PAULA, R.C.; CINTRA, G.S.; PEDRINHO, D.R.; CASALI, L.P.; PIZETTA, P.U.C.; PIMENTA, R.S. Effects of temperature on seed germination of Queen Palm Syagrus romanzoffiana (Cham.) Glassman. (Arecaceae). Acta Horticulturae, v.683, p.379-381, 2005 b. 
PIVETTA, K.F.L.; SARZI, I.; ESTELliTA, M.; SILVA, B.M.S.; CESARINO, F.; LIMA, J.D.; PANTOJA, BECKMANN-CAVALCANTE, M.Z. Tamanho do T.F.; MÔRO, F.V. Germinação de sementes e emergência de semente, substrato e temperatura na germinação de plântulas de Oenocarpus minor Mart. (Arecaceae). Revista sementes de Archontophoenix cunninghamii (Arecaceae). Revista de Biologia e Ciências da Terra, v.8, p.126-134, 2008.

Brasileira de Fruticultura, v.28, p.289-292, 2006.

TEIXEIRA, M.T.; VIEIRA, H.D.; PARTELLI, F.L.; SILVA, R.F. Despolpamento, armazenamento e temperatura POPINIGIS F. Fisiologia da semente. Brasília: Agiplan, 1977. 209p. na germinação de sementes de palmeira real australiana. Pesquisa Agropecuária Tropical, v.41, p.378-384, 2011. DOI: <http://www.scielo.br/pdf/pat/v41n3/a12v41n3.pdf> 